\title{
Who is jumping in a Serbian bog? - Orthopteran fauna of the Vlasina region
}

\author{
Slobodan Ivković ${ }^{1,2}$, Josip Skejo 1, 3
}

1 IUCN/SSC Grasshoppers Specialist Group

2 Department of Biogeography, Trier University, Universitätsring 15, 54286 Trier, Germany

3 University of Zagreb, Faculty of Science, Department of Biology, Division of Zoology, Evolution Lab, Zagreb, Croatia

Corresponding authors: Slobodan Ivković (s6slivko@uni-trier.de), Josip Skejo (skejo.josip@gmail.com)

Received 4 June 2020 | Accepted 21 September 2020 | Published 31 December 2020

Citation: Ivković S, Skejo J (2020) Who is jumping in a Serbian bog? - Orthopteran fauna of the Vlasina region. Travaux du Muséum National d'Histoire Naturelle "Grigore Antipa” 63(2): 141-160. https://doi.org/10.3897/ travaux.63.e55052

\begin{abstract}
Vlasina Plateau is a highland bog situated in the mountains of southeastern Serbia, close to the border with Bulgaria. From a conservation point of view, bogs are one of the most important habitats and they are considered as threatened all across Europe. As the Orthopteran fauna of southern European bogs has not been studied in detail, we decided to make an inventory of grasshoppers and bush-crickets of Vlasina region. During eight years (2012 to 2019) of orthopterological study, 63 species were recorded at Vlasina Plateau. Interesting findings are those of Balkan Field Grasshopper (Chorthippus bornhalmi) and Bures' Bush-cricket (Isophya bureschi) recently reported as first for Serbia, as well as regionally rare Serbian Pygmy Bush-cricket (Anterastes serbicus), Domogled Meadow Bush-cricket (Broughtonia domogledi), Short-winged Cone-head (Conocephalus dorsalis), Club-legged Grasshopper (Gomphocerus sibiricus), Fieber's Walking Bush-cricket (Psorodonotus fieberi) and Pygmy Toothed Grasshopper (Stenobothrus crassipes). In addition, we provided new distributional and bioacoustic data for Poecilimon pseudornatus and I. bureschi.
\end{abstract}

\section{Keywords}

Balkans, bogland, boreal, Broughtonia domogledi, bush-crickets, grasshoppers, IUCN, peatland, species-richness. 


\section{Introduction}

Peatlands are peculiar wet habitats rich in accumulated dead organic matter. They are characteristic for areas that meet several combined climatic and pedological features, such as high soil humidity with low nutrients as well as low annual and minimal temperature, and they usually appear across the Northern Hemisphere, the most numerous being those in taiga and tundra (Langheinrich et al. 2004). Despite their long-time recognized status of high conservation significance, due to ongoing climate change, increasing habitat degradation caused by human activities, and succession (Brigić et al. 2019), peatlands are still among the most vulnerable and endangered sites (Langheinrich et al. 2004). Well-studied peatlands in the Western Balkans are bogs, i.e. peatlands rich in Sphagnum (see e.g. Brigić et al. 2017), which are today small and disjunctive remnants of Pleistocene meadows exhibiting boreal fauna and flora (Horvat 1950; Topić and Stančić 2006). There are several peat bogs in Serbia, mainly in the southwestern and southeastern part of the country, some of them among the largest in the Balkans. Examples are the Pešter Plateau and Vlasina Plateau (Šovran et al. 2013). Vlasinsko blato (Vlasina mud) in southeastern Serbia was considered to be the largest peat bog in Balkan Peninsula prior to its submersion in the 1950s. Although most of its parts were submerged, crucial habitats with endemic and relict species survived, and amongst these species, the best known is the insectivorous Drosera rotundifolia L. (Ranđelović and Zlatković 2010). Today, the remaining peatland is conserved under the "Vlasina" Landscape of Outstanding Features. In this area, intensive research has been carried on numerous taxa, mostly vertebrates - birds (Puzović et al. 2009), reptiles and amphibians (Crnobrnja-Isailović et al. 2011; Dinov and Crnobrnja-Isailović 2013); but also some invertebrates - ants (Petrov 2011), butterflies (Tot et al. 2015; Tot et al. 2017), true bugs (Šeat 2017), hoverflies (Tot et al. 2018) and dragonflies (Đukić et al. 2019).

Literature data on Orthoptera of the Vlasina region are scarce (Pančić 1883; Adamović 1950, 1975; Skejo and Ivković 2015; Pavićević et al. 2014), so we aim to gather all historic data as well as new information related to the group in this peculiar peatland. We briefly present composition of the grasshoppers' assemblages at each locality, provide new data about song and distribution of Poecilimon pseudornatus and Isophya bureschi in Serbia and we put the highland into context of European Orthoptera fauna.

\section{Material and methods}

Studied area. Vlasina Plateau, situated in SE Serbia (Fig. 1), close to the border with Bulgaria, represents a mountainous peatbog in the centre of the Balkan Peninsula. Average height of area is from 1000 to $1300 \mathrm{~m}$ a.s.l. In the centre of plateau there is Vlasina Lake, laying at $1210 \mathrm{~m}$ a.s.l. The lake is surrounded by the numerous peaks - Čemernik Mt. (1638 m a.s.l.) to the west, Gramada Mt. (1721 m a.s.l.) to 


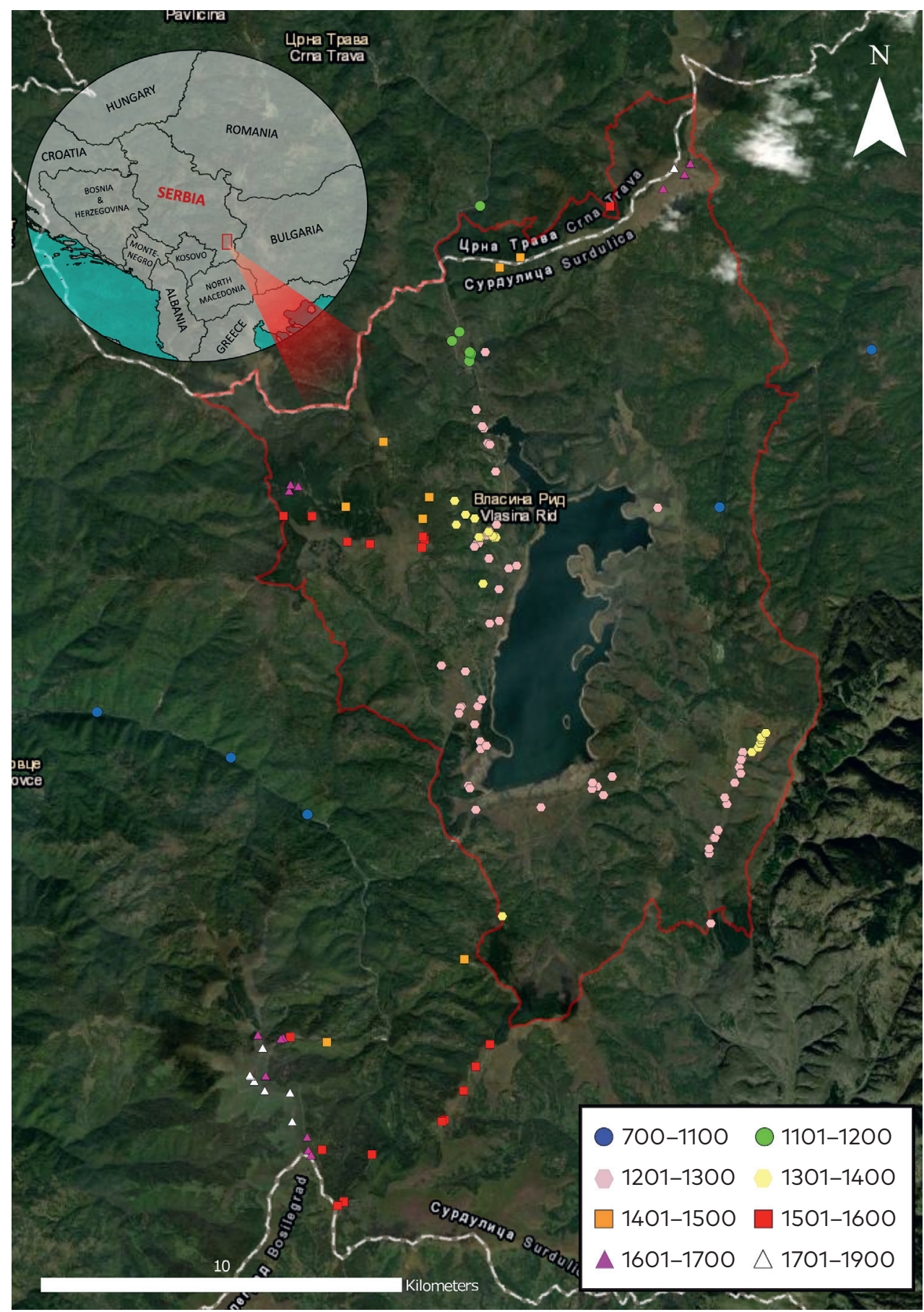

Figure 1. Map of investigated area. Markings represents visited localities listed in the Supplementary file. Red line represents area of "Vlasina" Landscape of outstanding features. 
the north and Vardenik Mt. (1875 m a.s.l.) to the south. Besides peat bog vegetation (Fig. 2D), which is dominant on Vlasina Plateau, different types of grasslands and pastures with dwarf-shrubs are present (Figs 2A, B, C), whereas forest vegetation is reduced to small fragments as a consequence of anthropogenic activities in the past (Ranđelović and Zlatković 2010).

Data collection. Orthoptera were investigated in the field on 151 localities between 2012 and 2019 (Fig. 1) by common entomological methods (visual and acoustic searching, sweep netting). All the species were identified to species level and usually photographed or collected for evidence. Part of collected material was pinned, while the majority was preserved in 96\% ethanol. Besides fieldwork investigations, amateur data on Orthoptera of Vlasina were collected from Serbian web pages specialized in biodiversity data accumulation and curation - Alciphron (Ivković 2014-2020) and Biologer (Popović et al. 2020). All detailed data are provided in Supplementary file 1.

Bioacoustic terminology. Audio recordings were taken with a Roland R-05 digital audio recorder (sampling rate $96 \mathrm{kHz}, 24$-bit amplitude resolution, microphone response frequency up to $40 \mathrm{kHz}$ ). Sound analysis and figures of the oscillo-
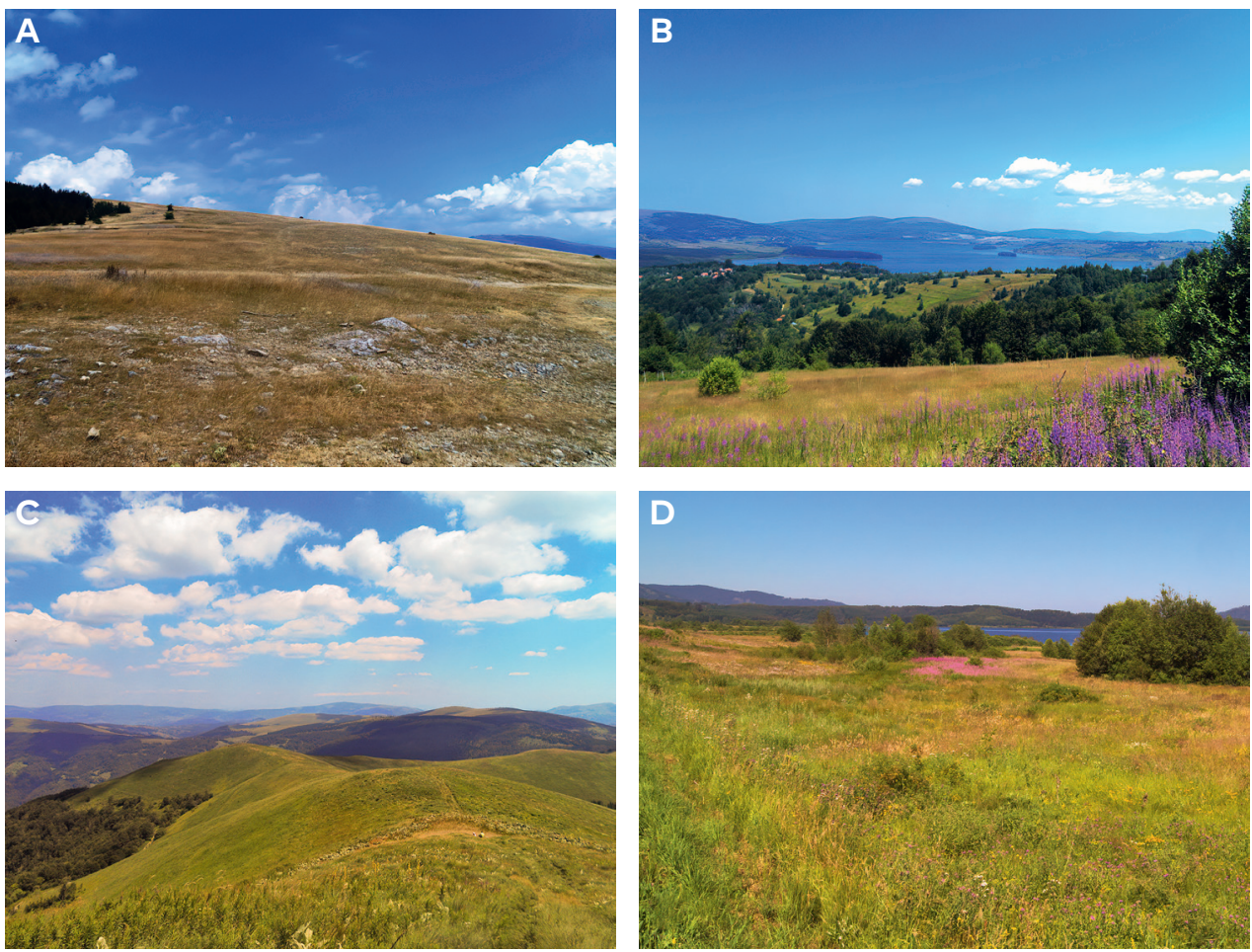

Figure 2. Different habitat types in Landscape of outstanding features "Vlasina": A, B - Vrtop (subalpine meadow with low vegetation; photo by Ivan Tot); C - Veliki Strešer (mountain grasslands; photo by Ivan Tot); D - Blato (hygrophilous meadow by the lake; photo by Slobodan Ivković). 
grams were prepared using Adobe Audio CC 2015 software. The song terminology follows Heller et al. (2004): calling song - song produced by an isolated male; functional unit of the song - the smallest part of the song, which contains all necessary song elements in appropriate order to elicit a female response; syllable - the sound produced by one complete up (opening) and down (closing) stroke of the forewings; impulse - a simple, undivided, transient train of sound waves; after-click - click produced with considerable delay after the main impulse group.

Identification and taxonomy. Specimens were determined using Harz (1969, 1975), Iorgu \& Iorgu (2008), Willemse (1985), Willemse et al. (2009), Chobanov et al. (2013), Chobanov and Heller (2010) and Bellman et al. (2019). Taxonomy and nomenclature follow Orthoptera Species File v5.0/5.0 (Cigliano et al. 2019); the chorotypes follow Popov (2007).

\section{Results}

Based on published data and results presented in this article, a total of 64 orthopteran species occur in the area of Vlasina lake. Of these, 30 belong to Ensifera and 34 to Caelifera. Four species - Oedipoda caerulescens (Linnaeus, 1758), reported by Adamović (1950), Oedaleus decorus (Germar, 1825), Chorthippus mollis (Charpentier, 1825) reported by Adamović (1975) and Poecilimon schmidtii (Fieber, 1853) (leg. M. Karaman, 17.7.1971), deposited in the Zoological Collection of the Department of Biology and Ecology at Novi Sad (ZZDBE), were not recorded during our surveys and they are thus not included in the list of species. We can expect that these species are still present in the area of Vlasina Lake, but during our field trips, we probably overlooked them.

In terms of chorology the species from Vlasina Lake belong to 17 categories - most numerous are species with Eurosiberian distribution (19), followed by the species with Central and South European (12), followed by Palearctic (8) Northern and Central Balkan (4), Eastern Mediterranean (3), Southeastern European (3), Western Palearctic (2), European (2), Central Balkan (2), Afrotropical-Palearctic (1), Balkan-Anatolian (1), European-Western Asian (1), Rila-Pirin-Slavyanka (1). Holomediterranean (1), South European (1), Turanian-Mediterranean (1), Holarctic (1) distribution.

\section{Notes on interesting species}

Isophya bureschi (Fig. 3A) - Until recently, this species was known in Serbia only from the Vlasina Plateau. Here, we report one new locality situated in Senokos, eastern Serbia (N $43.15901^{\circ}$, E $\left.22.93186^{\circ}\right)$. Stridulatory file in male from Senokos bears 72 teeth (Fig. 3B) and in two males from Vlasina Lake 66 and 71 teeth, while in both populations males have a long and pointed cercal tooth (Figs 3C-E). According to our observations, the song of I. bureschi can be heard from a distance 

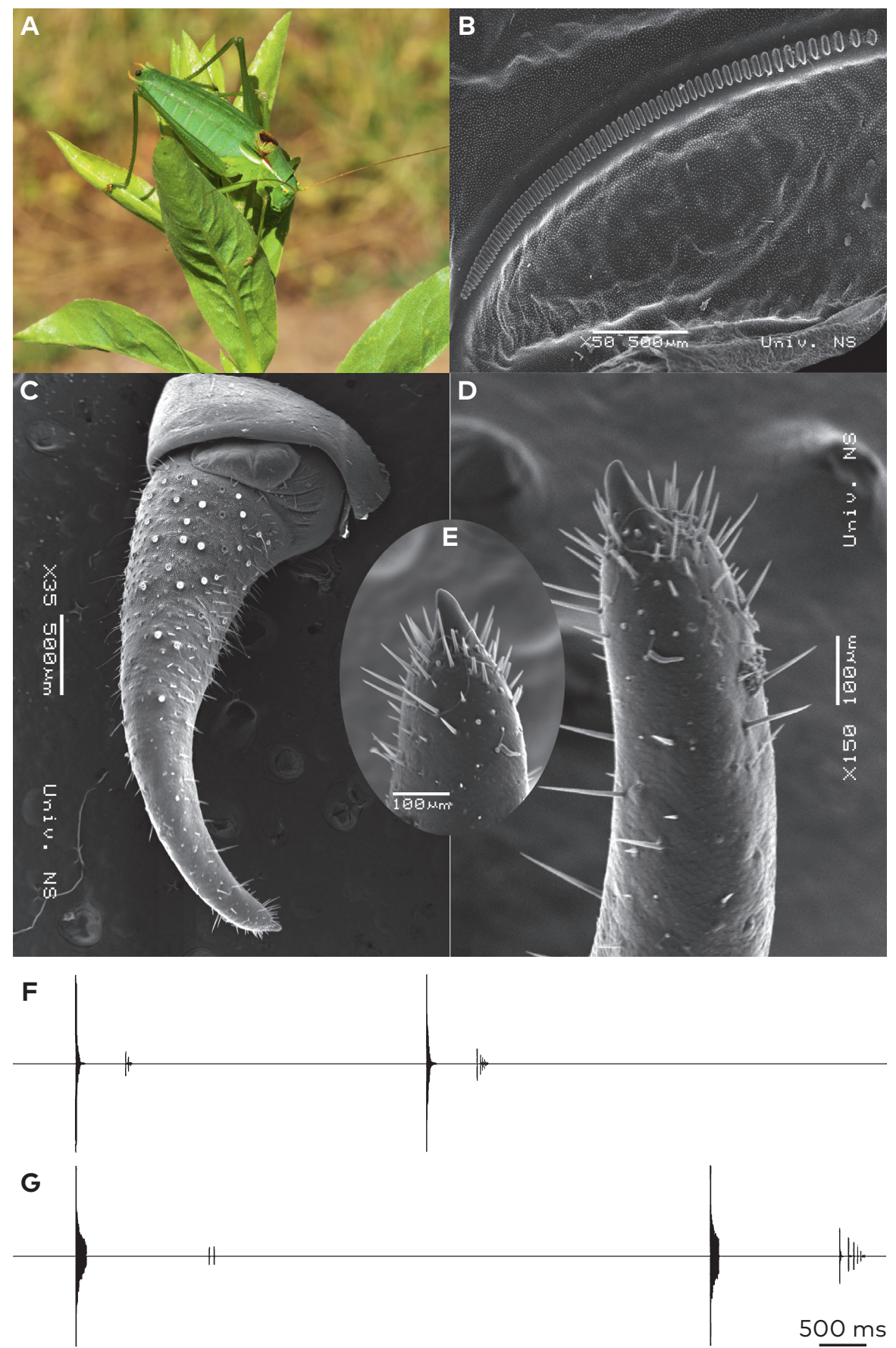

Figure 3. A - Bures' Plump Bush-cricket (Isophya bureschi), Senokos, 5 VII 2016; SEM photos of a male from Senokos; B - Stridulatory file; C - Cercus; D, E - Detailed view of a tooth on the tip of the cercus; F - Oscillographic sound analysis in a specimen from Čemernik Mt.; G - Oscillographic sound analysis in a specimen from Senokos. 
of about $20 \mathrm{~m}$, where males usually sing in the morning between 09:00-12:00 $\mathrm{h}$ and in the evening between 19:00-21:00 h. Their song consists of syllables that include a main part followed by an additional part of several after-clicks (Figs 3F, G). The main part of the syllable consists of 19-25 impulses and lasts 47-75 ms (mean $59.8 \pm 8)$ in specimens from Čemernik Mt. $\left(\mathrm{n}=10,26^{\circ} \mathrm{C}\right)$, whereas in specimens from Senokos $\left(\mathrm{n}=9,24^{\circ} \mathrm{C}\right)$, the main part consisted of 16-25 impulses and lasted 82-110 ms (mean 97.1 \pm 8.2 ). The additional part consisted of 3-7 separate impulses (after-clicks) in specimen from Čemernik Mt. and 4-7 in specimen from Senokos. Along with the after-clicks, the main syllable lasted between $563 \mathrm{~ms}$ and $679 \mathrm{~ms}$ (mean 639.4 \pm 35.4 ) in specimen from Čemernik Mt. and between 1.482 and 1.889 ms (mean 1758.2 \pm 128.2 ) in Senokos specimens.

Poecilimon pseudornatus (Figs 4B, C) - In Serbia, P. pseudornatus was reported from mountainous meadows and bushes in the western part of the country. After analysing the song of several populations (Table 2, Fig. 4A) in central and eastern Serbia, we discovered that $P$. pseudornatus has a wider distribution range, whereas the locality around Vlasina Lake represented the easternmost finding of
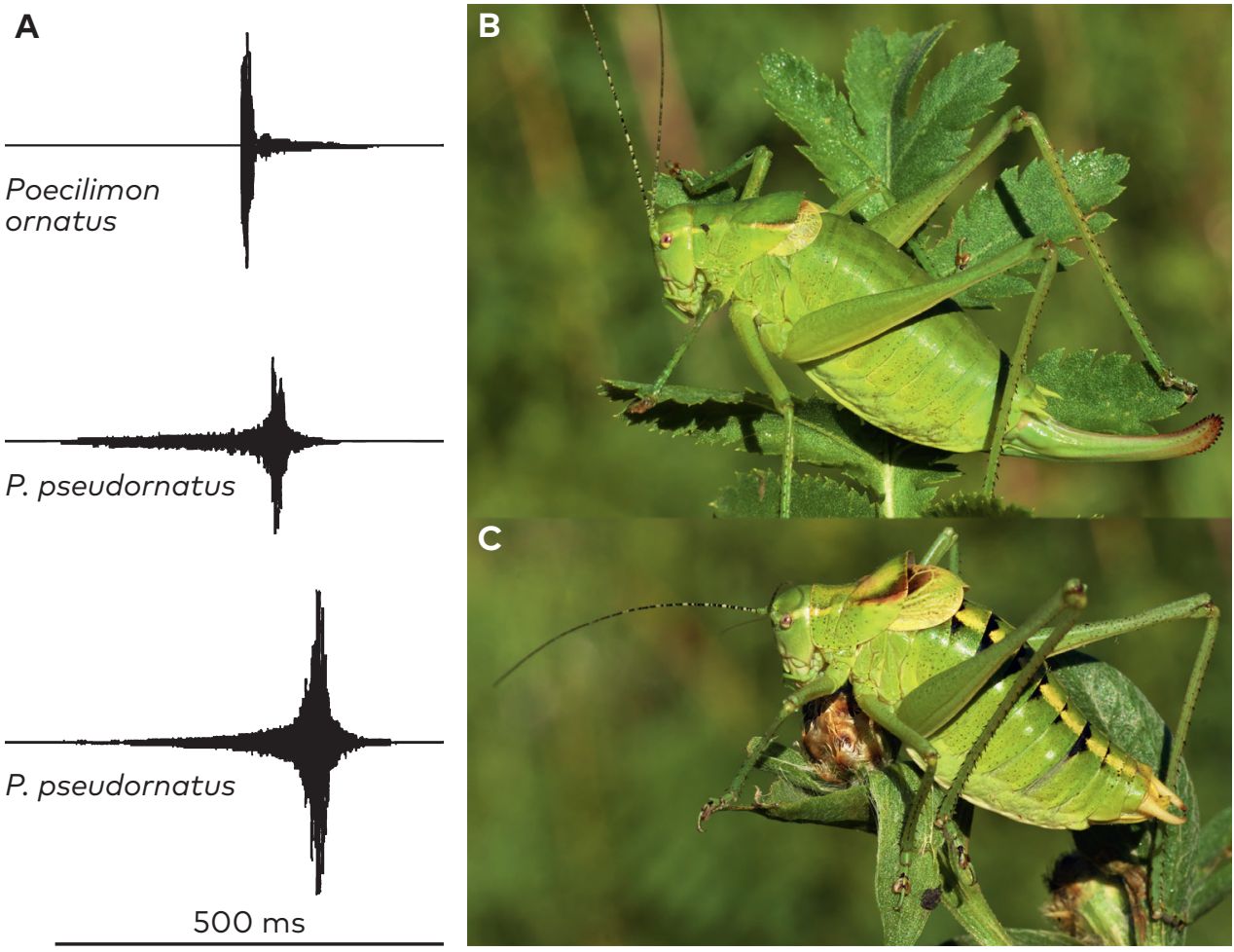

Figure 4. A - Oscilograms in Poecilimon ornatus, Slovenia (Gomboc and Šegula 2014), P. pseudornatus, Vlasina, Blato, P. pseudornatus - Radan Mt.; B - P. pseudornatus, female (Vlasina, Blato); C - P. pseudornatus, male (Vlasina, Blato). 


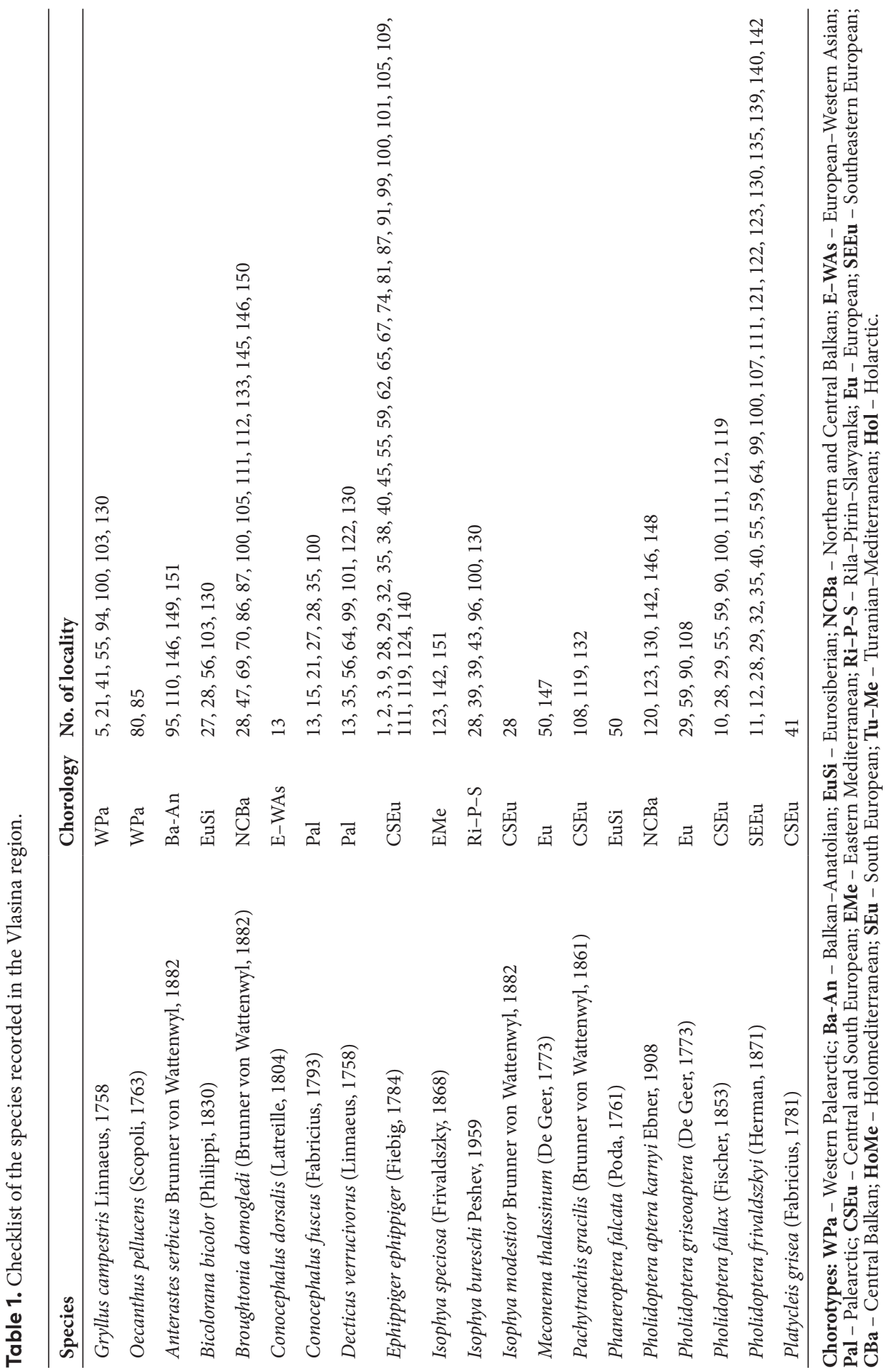




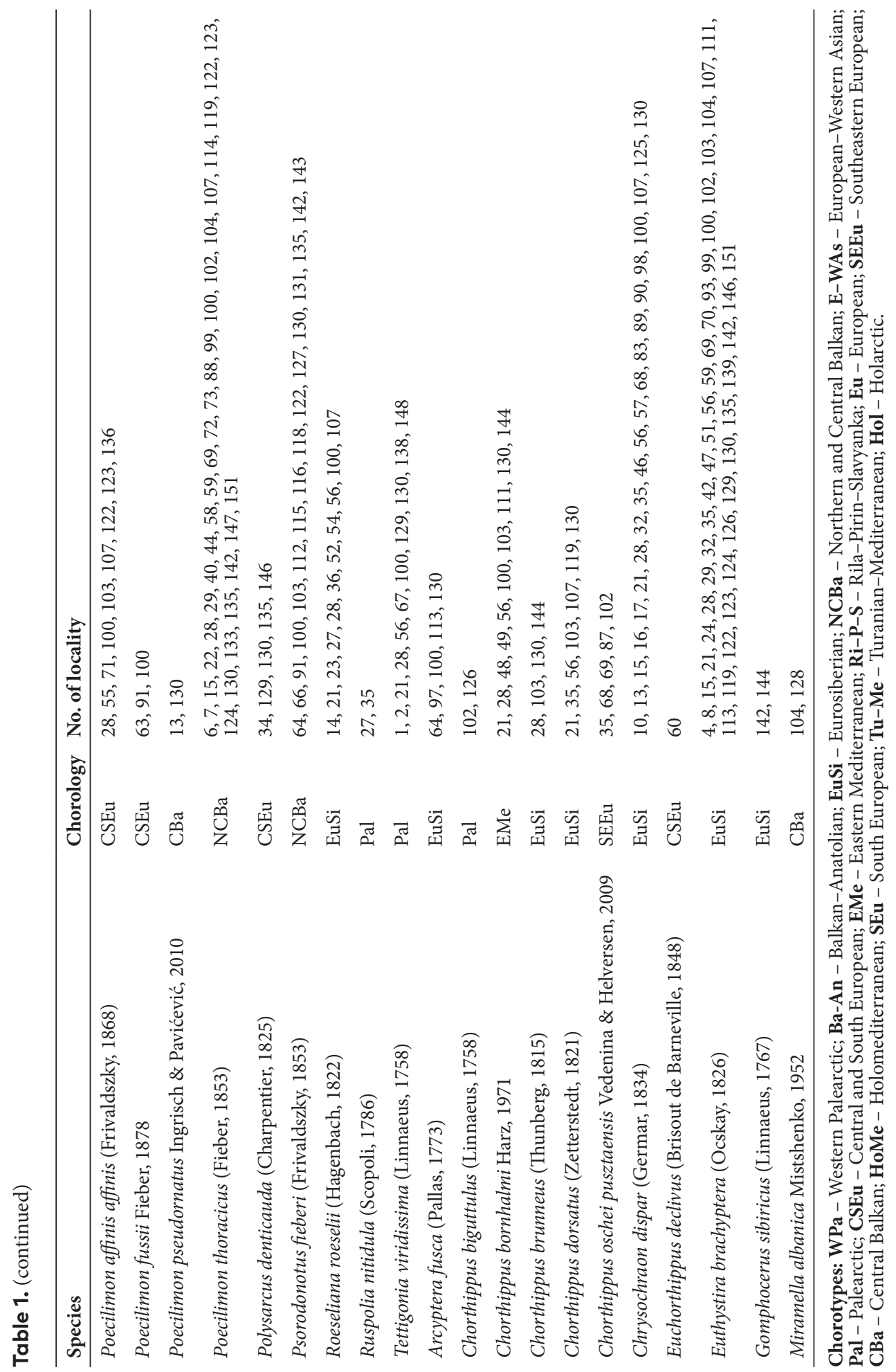




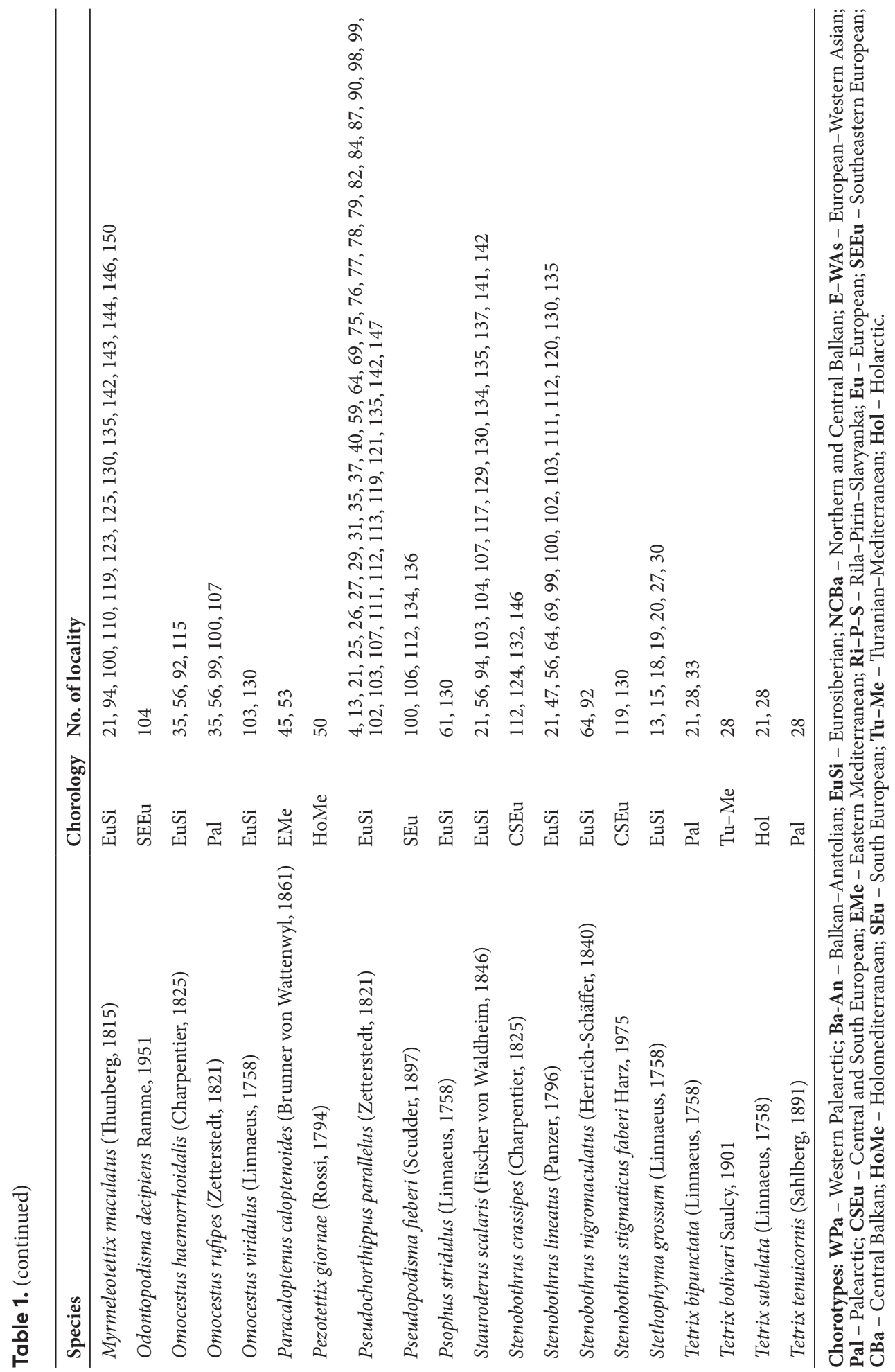


Table 2. Characters of the male stridulatory files and song in Poecilimon pseudornatus from different localities in Serbia

\begin{tabular}{lll}
\hline Source & $\begin{array}{l}\text { Number of } \\
\text { stridulatory teeth }\end{array}$ & $\begin{array}{l}\text { Syllable } \\
\text { duration }[\mathrm{ms}]\end{array}$ \\
\hline Pavićević and Ingrisch 2010 & $187-241$ & $225-252$ \\
Ivković 2017 & $181-381$ & $284-331$ \\
New data, Vlasina (n of syllables $\left.=5 ; 28{ }^{\circ} \mathrm{C}\right)$ & 235 & $320-342$ \\
New data Kopaonik, Brzeće (n of syllables $\left.=10 ; 30^{\circ} \mathrm{C}\right)$ & - & $210-236$ \\
New data, Radan Mt., Gornji Gajtan $\left(\right.$ n of syllables $\left.=10 ; 25^{\circ} \mathrm{C}\right)$ & - & $349-400$ \\
\hline
\end{tabular}

this species. New distribution data raised the question about the distribution of $P$. pseudornatus and P. affinis in Serbia (Fig. 5), a topic already discussed by Chobanov and Heller (2010). The main problems in this matter are the lack of research in Serbia and the fact that the previous authors used only the morphological details, whereas they did not use the song, which is the most significant character for distinguishing between the species from the $P$. ornatus group. Based on the analysed specimens, we can confirm that $P$. ornatus is not present in Serbia; thus, it has been confused with either $P$. pseudornatus or P. affinis.

\section{Discussion}

Orthopteran fauna of the alpine habitats of Serbia remains poorly studied; Grebenščikov (1950) provided data on orthoptera found on high mountains, but as his research data was obtained from several mountains in Serbia, it is not comparable with research presented in this article. To date, only Adamović and Mladenović (1993-94) provided information on the orthopteran fauna on peat bogs in Serbia to date, and they reported 23 species, most of which were found at Vlasina Plateau. Only two species reported by Adamović and Mladenović - Polysarcus scutatus (Brunner von Wattenwyl, 1882) and Broughtonia arnoldi (Ramme, 1933), were not reported from Vlasina Plateau.

The majority of the investigated species are endangered by habitat loss caused by the rapid tourism development in the area around Vlasina Lake. One of the endangered species is Broughtonia domogledi, whose populations are threatened with habitat destruction throughout their distribution range (Chobanov et al. 2016). We observed this species around Vlasina Lake in a tourist resort. Even though the species is very common on Vlasina Plateau in late summer, the conservation of its habitats is still necessary. Besides habitat loss, the greatest threat not only to Orthoptera, but to the entire flora and fauna of Vlasina Plateau, are small hydropower plants constructed on several rivers in Crna Trava municipality. Regardless of the fact that Vlasina Lake is man-made, extensive changes, such as water regime changes, can 


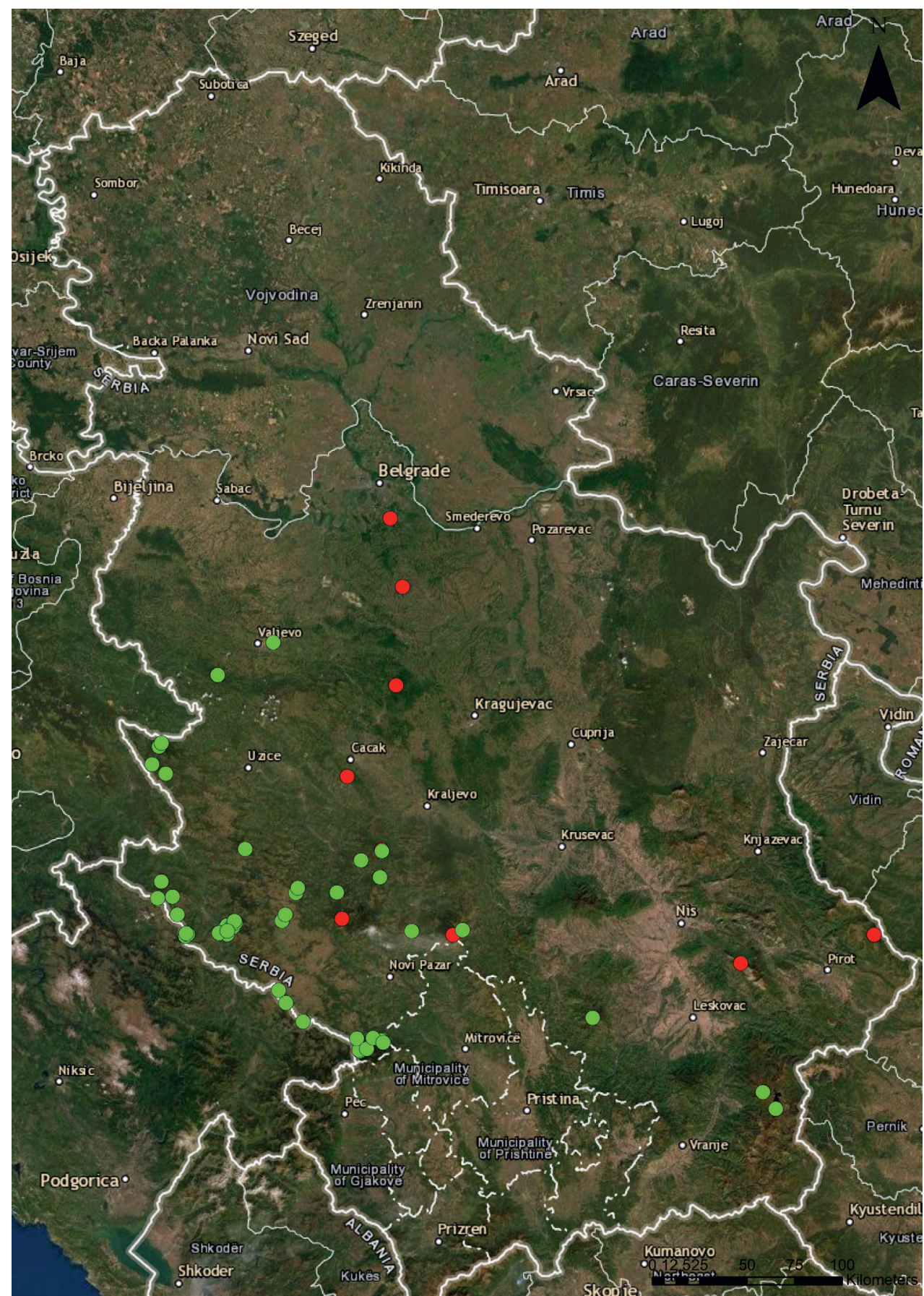

Figure 5. Distribution map of Poecilimon pseudornatus (green circles) together with literature data on P. affinis/P. ornatus (red circles). 
endanger hygrophilous species through the disappearance of bogs and habitat homogenisation.

\section{Acknowledgments}

We are thankful to to the authority of the Protected Landscape Vlasina "PE Surdulica Municipality Land Development Directorate" for technical support and accommodation, to Milan Đurić for improving the English, to Dora Papković for the proofreading and Miloš Bokorov for SEM support. The field surveys were made as a part of regular field studies by Scientific Research Society of Biology and Ecology Students "Josif Pančić" (Novi Sad). We would like to thank Aleksandar Đukić, Bojana Nadaždin, Emanuel Veverica, Ivan Tot, Mihajlo Vujić, Milan Đurić, Miloš Popović, Nikola Veljković, Slobodan Stevčić and Vladimir Žikić for sharing data on Alciphron and Biologer. We thank the anonymous reviewers for improving the quality of this manuscript.

IS research on Isophya bureschi and Poecilimon pseudornatus were funded by Orthoptera Species File Grants 2016-2019 and DGfO grant (Phylogeny and systematics of the Western Balkans Isophya and Poecilimon).

JS thanks to Draženko Rajković for the organization and for providing facilities; to Radislav Mirić, Ivan Tot and Anja Slacki for their help in fieldwork and photography. Many thanks to Novica Stanković and other rangers, who made it possible for us to pick and visit unreachable localities. JS sends special thanks to Jelena Gavrilov and Tamara Jovanović, for all the help during the journey and during the filed.

\section{References}

Adamović ŽR (1950) Neke biometrijske analize na Oedipoda caerulescens L. (Orthoptera) [Some biometric analyzes on Oedipoda caerulescens L. (Orthoptera)]. Glasnik Prirodnjačkog muzeja Beograd, B 3-4: 333-340. [in Serbian]

Adamović ŽR (1975) Pregled vrsta Mantodea i Saltatoria nađenih u SR Srbiji [Review of the species of Mantodea and Saltatoria recorded in Serbia]. SANU, Zbornik radova o entomofauni SR Srbije, Beograd. [in Serbian]

Adamović ŽR, Mladenović A (1993-94) An Orthoptera examination of two peat-bogs in Mt Stara Planina (E Serbia). Glasnik Prirodnjačkog muzeja Beograd, B 48: 139-145.

Bellmann H, Rutschmann F, Roesti C, Hochkirch A (2019) Der Kosmos Heuschreckenführer [The Kosmos guide to Orthoptera]. Franckh Kosmos Verlag, Stuttgart, 430 pp. [in German] Brigić A, Bujan J, Alegro A, Šegota V, Ternjej I (2017) Spatial distribution of insect indicator taxa as a basis for peat bog conservation planning. Ecological indicators 80: 344-353.

Brigić A, Bujan J, Bedek J, Antonović I, Sedlar Z, Šoštarić R, Kepčija RM (2019) Spatiotemporal changes of terrestrial isopod assemblages (Isopoda: Oniscidea) in a fen undergoing succession. Pedobiologia 72: 16-22. 
Chobanov D, Grzywacz B, Iorgu I, Ciplak B, Ilieva M, Warchałowska-Śliwa E (2013) Review of the Balkan Isophya (Orthoptera: Phaneropteridae) with particular emphasis on the Isophya modesta group and remarks on the systematics of the genus based on morphological and acoustic data. Zootaxa 3658(1): 1-81.

Chobanov D, Heller KG (2010) Revision of the Poecilimon ornatus group (Orthoptera: Phaneropteridae) with focus on Bulgaria and Macedonia. European Journal of Entomology 107: 647-672.

Chobanov DP, Hochkirch A, Iorgu IS, Ivkovic S, Kristin A, Lemonnier-Darcemont M, Pushkar T, Sirin D, Skejo J, Szovenyi G, Vedenina V, Willemse LPM (2016). Broughtonia domogledi. The IUCN Red List of Threatened Species 2016: e.T64551374A70271673. https://dx.doi.org/10.2305/IUCN.UK.2016-3.RLTS. T64551374A70271673.en. Downloaded on 25 May 2020.

Cigliano MM, Braun H, Eades DC, Otte D (2018) Orthoptera Species File. Version 5.0/5.0. [28.07.2018]. <http://Orthoptera.SpeciesFile.org>.

Crnobrnja-Isailović J, Dinov J, Ranđjelović V (2011) Occurrence of European Adder (Vipera berus, Viperidae, Ophidia) on Vlasina Plateau (Southeastern Serbia). Biologica Nyssana 2(1): 81-84.

Dinov J, Crnobrnja-Isailović J (2013) Species richness of amphibian and reptile fauna on Vlasina plateau. 11th Symposium on the flora of southeastern Serbia and neighbouring regions, Vlasina lake, Serbia. Abstract Book, p. 123.

Đukić A, Mirić R, Skejo J, Rajkov S, Tot I (2019) Survey on the damselfly and dragonfly fauna (Insecta: Odonata) of the Landscape of outstanding features "Vlasina”. Kragujevac Journal of Science (41): 133-146.

Grebenščikov O (1950) Prilog poznavanju visokoplaninske faune skakavaca (Orthoptera) istočne Jugoslavije [Contribution to the knowledge of the high mountain locusts (Orthoptera) fauna of eastern Yugoslavia]. Zbornik radova Instituta za ekologiju i biogeografiju Beograd 1: 181-195. [in Serbian]

Harz K (1969) Die Orthopteren Europas [The Orthoptera of Europe]. Vol. I. Dr. W Junk N.V., The Hague, 749 pp.

Harz K (1975) Die Orthopteren Europas [The Orthoptera of Europe]. Vol. II. Dr. W Junk N.V., The Hague, 939 pp.

Heller KG, Orci KM, Grein G, Ingrisch S (2004) The Isophya species of Central and Western Europe (Orthoptera: Tettigonioidea, Phaneropteridae). Tijdschrift voor Entomologie 147: 237-258.

Horvat I (1950) Flornogenetski odnosi cretova u Hrvatskoj [The genetic relationships of bog vegetation in Croatia]. Periodicum Biologorum 2: 13-21. [in Croatian]

Iorgu IŞ, Iorgu EI (2008) Bush-crickets, crickets and grasshoppers from Moldavia (Romania). Editura Pim, Iaşi, 294 pp.

Ivković S [ur.] (2014-2020) Alciphron - baza podataka o insektima Srbije (Orthoptera), HabiProt [Alciphron - database on insects in Serbia (Orthoptera), HabiProt]. http:// www.alciphron.habiprot.org.rs [accessed on 12/04/2020]. 
Langheinrich U, Tischew S, Gersberg RM, Lüderitz V (2004) Ditches and canals in management of fens: opportunity or risk? A case study in the Drömling Natural Park, Germany. Wetlands Ecology and Management 12: 429-445.

PančićJ (1883) Orthoptera in Serbia hucdum detecta [Orthoptera in Serbia] . Kraljevskosrpska državna štampa, Beograd 172 p. [in Latin]

Pavićević D, Ivković S, Horvat L (2014) New and rare species of orthopteroid insects in the fauna of Serbia. Fauna Balkana 3: 103-122.

Petrov I (2011) Contribution to the Myrmecofauna (Hymenoptera, Formicidae) of the area of Vlasinsko jezero (Vlasina lake) (Serbia). Bulletin of the Natural History Museum 2: 127-129.

Popov A (2007) Fauna and Zoogeography of the Orthopterid Insects (Embioptera, Dermaptera, Mantodea, Blattodea, Isoptera, and Orthoptera) in Bulgaria. In: Biogeography and Ecology of Bulgaria. Springer, Dordrecht, pp. 233-295.

Popović M, Vasić N, Koren T, Burić I, Živanović N, Kulijer D, Golubović A (in press) Biologer: an open platform for collecting biodiversity data. Biodiversity Data Journal.

Puzović S, Sekulić G, Stojnić N, Grubač B, Tucakov M (2009) Important Bird Areas in Serbia. Belgrade: Ministry of Environment and Spatial Planning, Institute for Nature Conservation of Serbia, Provincial Secretariat of Environmental Protection and Sustainable Development.

Ranđelović VN, Zlatković BK (2010) Flora i vegetacija Vlasinske visoravni [Flora and vegetation of Vlasina Plateau]. Prirodno-matematički fakultet, Niš. 459 pp. [in Serbian]

Šeat J (2017) Contribution to the knowledge on true bugs (Insecta: Heteroptera) of Vlasina. Zaštita Prirode 67(1-2): 43-54.

Skejo J, Ivković S (2015) Chorthippus bornhalmi in the heart of the Balkans (Acrididae: Gomphocerinae). Articulata 30: 81-90.

Šovran S, Jovanović V, Krizmanić J, Cvijan M (2013) Desmid flora from four peat bogs in Serbia. Archives of Biological Sciences 65(2): 721-732.

Topić J, Stančić Z (2006) Extinction of fen and bog plants and their habitats in Croatia. Biodiversity and Conservation 15: 3371-3381.

Tot I, Slacki A, Đurić M, Popović M (2015) Butterflies of the Vlasina region in southeast Serbia (Lepidoptera: Papilionoidea). Acta entomologica serbica 20: 117-135.

Tot I, Đurić M, Popović M (2017) Butterflies of Vlasina. PE “Direkcija za građevinsko zemljište i puteve opštine Surdulica" and HabiProt, Surdulica, 152 pp.

Tot T, Vujić M, Likov L, Nedeljković Z, Radenković S, Vujić A (2018) Hoverfly fauna (Diptera: Syrphidae) of the Landscape of Outstanding Features „Vlasina“. Acta entomologica serbica 23: 33-50.

Willemse F, Helversen O von, Odé B (2009) A review of Chorthippus species with angled pronotal lateral keels from Greece with special reference to transitional populations between some Peloponnesean taxa (Orthoptera, Acrididae). Zoologische Mededelingen 83(2): 319-507.

Willemse FMH (1985) Fauna Graeciae II. A key to the Orthoptera species of Greece. Hellenic Zoological Society, Athens. 
Appendix 1. Detailed data on the investigated sites.

\begin{tabular}{|c|c|c|c|c|c|c|}
\hline Locality No & Northing & Easting & Collector/Publication & Date & $\begin{array}{l}\text { UTM } \\
10 \times 10 \\
\end{array}$ & $\begin{array}{c}\text { Altitude } \\
\text { m a.s.l. }\end{array}$ \\
\hline 1 & 42.6932 & 22.2293 & Slobodan Ivković & 04 IX 2019 & FN02 & 650 \\
\hline 2 & 42.6849 & 22.2627 & Slobodan Ivković & 04 IX 2019 & FN02 & 767 \\
\hline 3 & 42.6744 & 22.2818 & Slobodan Ivković & 04 IX 2019 & FN02 & 907 \\
\hline 4 & 42.7596 & 22.4225 & Bojana Nadaždin & 21 VII 2019 & FN13 & 982 \\
\hline 5 & 42.7308 & 22.3846 & Mihailo Vujić & $20 \mathrm{~V} 2017$ & FN13 & 1091 \\
\hline 6 & 42.7859 & 22.3248 & Milan Đurić & 13 VIII 2019 & FN03 & 1157 \\
\hline 7 & 42.7584 & 22.3224 & Slobodan Stevčić & 13 VIII 2019 & FN03 & 1176 \\
\hline 8 & 42.7575 & 22.3222 & Emanuel Veverica & 23 VI 2019 & FN03 & 1176 \\
\hline 9 & 42.7612 & 22.3179 & Slobodan Stevčić & 13 VIII 2019 & FN03 & 1181 \\
\hline 10 & 42.7628 & 22.3197 & Mihailo Vujić & 13 VIII 2019 & FN03 & 1183 \\
\hline 11 & 42.7589 & 22.3226 & Slobodan Stevčić & 23 VI 2019 & FN03 & 1192 \\
\hline 12 & 42.7592 & 22.3222 & Slobodan Stevčić & 23 VII 2019 & FN03 & 1193 \\
\hline 13 & 42.6757 & 22.3400 & Slobodan Ivković & 15 VII 2012 & FN02 & 1208 \\
\hline 14 & 42.6795 & 22.3541 & Nikola Veljković & 23 VII 2019 & FN12 & 1209 \\
\hline 15 & 42.6780 & 22.3556 & Slobodan Ivković & 15 VII 2012 & FN12 & 1210 \\
\hline 16 & 42.6753 & 22.3238 & Nikola Veljković & 26 VII 2018 & FN02 & 1210 \\
\hline 17 & 42.6864 & 22.3250 & Nikola Veljković & 24 VII 2019 & FN02 & 1211 \\
\hline 18 & 42.6878 & 22.3249 & Nikola Veljković & 24 VII 2019 & FN02 & 1211 \\
\hline 19 & 42.6797 & 22.3219 & Nikola Veljković & 24 VII 2019 & FN02 & 1211 \\
\hline 20 & 42.6864 & 22.3250 & Nikola Veljković & 24 VII 2019 & FN02 & 1211 \\
\hline 21 & 42.7099 & 22.3296 & Skejo and Ivković (2015) & 17 VII 2014 & FN02 & 1212 \\
\hline 22 & 42.7200 & 22.334 & Mihailo Vujić & 12 VII 2017 & FN03 & 1212 \\
\hline 23 & 42.6792 & 22.3223 & Nikola Veljković & 24 VII 2019 & FN02 & 1212 \\
\hline 24 & 42.6792 & 22.3529 & Nikola Veljković & 23 VII 2019 & FN12 & 1212 \\
\hline 25 & 42.6791 & 22.3528 & Nikola Veljković & 23 VII 2019 & FN12 & 1212 \\
\hline 26 & 42.6910 & 22.3235 & Nikola Veljković & 24 VII 2019 & FN02 & 1212 \\
\hline 27 & 42.7452 & 22.3257 & Slobodan Ivković & 13 VII 2012 & FN03 & 1213 \\
\hline 28 & 42.7456 & 22.3254 & Skejo and Ivković (2015) & 14 VII 2014 & FN03 & 1213 \\
\hline 29 & 42.7095 & 22.3273 & Slobodan Ivković & 04 IX 2019 & FN02 & 1213 \\
\hline 30 & 42.6870 & 22.3264 & Nikola Veljković & 24 VII 2019 & FN02 & 1213 \\
\hline 31 & 42.6943 & 22.3243 & Nikola Veljković & 24 VII 2019 & FN02 & 1214 \\
\hline 32 & 42.6545 & 22.3824 & Mihailo Vujić & 16 VIII 2019 & FN12 & 1215 \\
\hline 33 & 42.6802 & 22.3529 & Slobodan Stevčić & 22 VI 2019 & FN12 & 1215 \\
\hline 34 & 42.7195 & 22.3320 & Vladimir Žikić & 28 VI 2012 & FN03 & 1218 \\
\hline
\end{tabular}


Appendix 1. (continued)

\begin{tabular}{|c|c|c|c|c|c|c|}
\hline Locality No & Northing & Easting & Collector/Publication & Date & $\begin{array}{c}\text { UTM } \\
10 \times 10\end{array}$ & $\begin{array}{c}\text { Altitude } \\
\text { m a.s.l. }\end{array}$ \\
\hline 35 & 42.6942 & 22.3202 & Slobodan Ivković & 04 IX 2019 & FN02 & 1219 \\
\hline 36 & 42.6941 & 22.3199 & Slobodan Ivković & 04 IX 2019 & FN02 & 1221 \\
\hline 37 & 42.6955 & 22.3253 & Nikola Veljković & 24 VII 2019 & FN02 & 1227 \\
\hline 38 & 42.6930 & 22.3196 & Milan Đurić & 12 VII 2019 & FN02 & 1231 \\
\hline 39 & 42.7372 & 22.3287 & Pavićević et al. (2014) & 10 VII 2008 & FN03 & 1231 \\
\hline 40 & 42.7158 & 22.3295 & Slobodan Ivković & 04 IX 2019 & FN03 & 1234 \\
\hline 41 & 42.7306 & 22.3692 & Slobodan Ivković & 16 VII 2012 & FN13 & 1238 \\
\hline 42 & 42.6673 & 22.3820 & Milan Đurić & 15 VII 2019 & FN12 & 1239 \\
\hline 43 & 42.7006 & 22.3212 & Pavićević et al. (2014) & 15 VII 2014 & FN02 & 1241 \\
\hline 44 & 42.7486 & 22.3239 & Slobodan Ivković & 13 VII 2012 & FN03 & 1241 \\
\hline 45 & 42.6702 & 22.3832 & Slobodan Ivković & 02 IX 2019 & FN12 & 1243 \\
\hline 46 & 42.6682 & 22.3820 & Mihailo Vujić & 16 VIII 2019 & FN12 & 1243 \\
\hline 47 & 42.6702 & 22.3834 & Slobodan Ivković & 02 IX 2019 & FN12 & 1244 \\
\hline 48 & 42.7426 & 22.3267 & Slobodan Stevčić & 22 VI 2019 & FN03 & 1245 \\
\hline 49 & 42.7424 & 22.3268 & Slobodan Stevčić & 23 VII 2019 & FN03 & 1245 \\
\hline 50 & 42.7422 & 22.3273 & Ivan Tot & 04 IX 2016 & FN03 & 1247 \\
\hline 51 & 42.6814 & 22.3578 & Slobodan Stevčić & 27 V 2018 & FN12 & 1247 \\
\hline 52 & 42.6714 & 22.3842 & Slobodan Ivković & 02 IX 2019 & FN12 & 1256 \\
\hline 53 & 42.6716 & 22.3842 & Slobodan Ivković & 02 IX 2019 & FN12 & 1259 \\
\hline 54 & 42.7213 & 22.3270 & Slobodan Ivković & 04 IX 2019 & FN03 & 1261 \\
\hline 55 & 42.7017 & 22.3152 & Skejo and Ivković (2015) & 17 VII 2014 & FN02 & 1264 \\
\hline 56 & 42.7017 & 22.3152 & Skejo and Ivković (2015) & 17 VII 2014 & FN02 & 1264 \\
\hline 57 & 42.6763 & 22.3865 & Slobodan Ivković & 02 IX 2019 & FN12 & 1264 \\
\hline 58 & 42.7591 & 22.3261 & Slobodan Stevčić & 13 VIII 2019 & FN03 & 1272 \\
\hline 59 & 42.7213 & 22.3270 & Slobodan Ivković & 04 IX 2019 & FN03 & 1273 \\
\hline 60 & 42.6775 & 22.3859 & Slobodan Ivković & 02 IX 2019 & FN12 & 1275 \\
\hline 61 & 42.6803 & 22.3884 & Slobodan Ivković & 02 IX 2019 & FN12 & 1280 \\
\hline 62 & 42.7240 & 22.3239 & Slobodan Ivković & 02 IX 2019 & FN03 & 1286 \\
\hline 63 & 42.6831 & 22.3895 & Slobodan Ivković & 02 IX 2019 & FN12 & 1286 \\
\hline 64 & 42.6819 & 22.3899 & Bojana Nadaždin & 24 VII 2019 & FN12 & 1287 \\
\hline 65 & 42.7242 & 22.3245 & Slobodan Ivković & 02 IX 2019 & FN03 & 1288 \\
\hline 66 & 42.6848 & 22.3901 & Slobodan Ivković & 02 IX 2019 & FN12 & 1291 \\
\hline 67 & 42.7235 & 22.3234 & Slobodan Ivković & 02 IX 2019 & FN03 & 1295 \\
\hline 68 & 42.6858 & 22.3904 & Slobodan Ivković & 02 IX 2019 & FN12 & 1295 \\
\hline
\end{tabular}


Appendix 1. (continued)

\begin{tabular}{|c|c|c|c|c|c|c|}
\hline Locality No & Northing & Easting & Collector/Publication & Date & $\begin{array}{c}\text { UTM } \\
10 \times 10\end{array}$ & $\begin{array}{c}\text { Altitude } \\
\text { m a.s.l. }\end{array}$ \\
\hline 69 & 42.7275 & 22.3290 & Slobodan Ivković & 01 IX 2019 & FN03 & 1297 \\
\hline 70 & 42.6845 & 22.3900 & Slobodan Ivković & 02 IX 2019 & FN12 & 1298 \\
\hline 71 & 42.7257 & 22.3265 & Slobodan Ivković & 02 IX 2019 & FN03 & 1299 \\
\hline 72 & 42.7264 & 22.3271 & Mihailo Vujić & 11 VII 2017 & FN03 & 1299 \\
\hline 73 & 42.7255 & 22.3263 & Nikola Veljković & 26 VII 2019 & FN03 & 1299 \\
\hline 74 & 42.7251 & 22.3286 & Slobodan Ivković & 02 IX 2019 & FN03 & 1301 \\
\hline 75 & 42.7253 & 22.3287 & Nikola Veljković & 23 VII 2019 & FN03 & 1301 \\
\hline 76 & 42.7254 & 22.3286 & Nikola Veljković & 23 VII 2019 & FN03 & 1301 \\
\hline 77 & 42.7254 & 22.3286 & Nikola Veljković & 23 VII 2019 & FN03 & 1301 \\
\hline 78 & 42.7254 & 22.3286 & Nikola Veljković & 23 VII 2019 & FN03 & 1301 \\
\hline 79 & 42.7254 & 22.3286 & Nikola Veljković & 23 VII 2019 & FN03 & 1301 \\
\hline 80 & 42.7252 & 22.3284 & Slobodan Ivković & 02 IX 2019 & FN03 & 1302 \\
\hline 81 & 42.7252 & 22.3249 & Slobodan Ivković & 02 IX 2019 & FN03 & 1302 \\
\hline 82 & 42.7254 & 22.3286 & Nikola Veljković & 23 VII 2019 & FN03 & 1303 \\
\hline 83 & 42.7252 & 22.3289 & Nikola Veljković & 23 VII 2019 & FN03 & 1304 \\
\hline 84 & 42.7252 & 22.3288 & Nikola Veljković & 23 VII 2019 & FN03 & 1304 \\
\hline 85 & 42.7255 & 22.3280 & Slobodan Ivković & 02 IX 2019 & FN03 & 1305 \\
\hline 86 & 42.7262 & 22.3270 & Slobodan Ivković & 02 IX 2019 & FN03 & 1305 \\
\hline 87 & 42.7253 & 22.3246 & Slobodan Ivković & 01 IX 2019 & FN03 & 1310 \\
\hline 88 & 42.7287 & 22.3235 & Slobodan Ivković & 01 IX 2019 & FN03 & 1320 \\
\hline 89 & 42.7167 & 22.3256 & Nikola Veljković & 25 VII 2019 & FN03 & 1322 \\
\hline 90 & 42.7294 & 22.3212 & Slobodan Ivković & 01 IX 2019 & FN03 & 1324 \\
\hline 91 & 42.6859 & 22.3927 & Slobodan Ivković & 02 IX 2019 & FN12 & 1337 \\
\hline 92 & 42.6867 & 22.3943 & Slobodan Ivković & 02 IX 2019 & FN12 & 1364 \\
\hline 93 & 42.7319 & 22.3185 & Milan Đurić & 18 IX 2018 & FN03 & 1368 \\
\hline 94 & 42.6876 & 22.3949 & Slobodan Ivković & 02 IX 2019 & FN12 & 1371 \\
\hline 95 & 42.6875 & 22.3948 & Slobodan Ivković & 02 IX 2019 & FN12 & 1373 \\
\hline 96 & 42.6882 & 22.3951 & Slobodan Ivković & 02 IX 2019 & FN12 & 1377 \\
\hline 97 & 42.6886 & 22.395 & Slobodan Ivković & 02 IX 2019 & FN12 & 1383 \\
\hline 98 & 42.7275 & 22.3189 & Slobodan Stevčić & 07 IX 2018 & FN03 & 1388 \\
\hline 99 & 42.6894 & 22.3961 & Slobodan Ivković & 02 IX 2019 & FN12 & 1400 \\
\hline 100 & 42.6558 & 22.3304 & Skejo and Ivković (2015) & 19 VII 2014 & FN02 & 1424 \\
\hline 101 & 42.7326 & 22.3121 & Bojana Nadaždin & 19 IX 2018 & FN03 & 1444 \\
\hline 102 & 42.7428 & 22.3007 & Mihailo Vujić & 03 IX 2019 & FN03 & 1450 \\
\hline
\end{tabular}


Appendix 1. (continued)

\begin{tabular}{|c|c|c|c|c|c|c|}
\hline Locality No & Northing & Easting & Collector/Publication & Date & $\begin{array}{c}\text { UTM } \\
10 \times 10\end{array}$ & $\begin{array}{c}\text { Altitude } \\
\text { m a.s.l. }\end{array}$ \\
\hline 103 & 42.7747 & 22.3297 & Skejo and Ivković (2015) & 17 VII 2014 & FN03 & 1453 \\
\hline 104 & 42.6327 & 22.2866 & Ivan Tot & 24 VII 2019 & FN02 & 1461 \\
\hline 105 & 42.6478 & 22.3208 & Nikola Veljković & 28 VII 2018 & FN02 & 1464 \\
\hline 106 & 42.6478 & 22.3209 & Nikola Veljković & 28 VII 2018 & FN02 & 1464 \\
\hline 107 & 42.7308 & 22.2913 & Mihailo Vujić & 03 IX 2019 & FN03 & 1466 \\
\hline 108 & 42.7765 & 22.3349 & Slobodan Ivković & 13 VII 2012 & FN03 & 1471 \\
\hline 109 & 42.7286 & 22.3105 & Ivan Tot & 19 IX 2018 & FN03 & 1482 \\
\hline 110 & 42.6184 & 22.3159 & Bojana Nadaždin & 22 VII 2019 & FN01 & 1512 \\
\hline 111 & 42.6238 & 22.3207 & Slobodan Ivković & 02 IX 2019 & FN01 & 1513 \\
\hline 112 & 42.6181 & 22.3153 & Slobodan Ivković & 02 IX 2019 & FN01 & 1518 \\
\hline 113 & 42.7247 & 22.3109 & Slobodan Stevčić & 07 IX 2018 & FN03 & 1519 \\
\hline 114 & 42.7234 & 22.3103 & Milan Đurić & 14 VII 2018 & FN03 & 1521 \\
\hline 115 & 42.7253 & 22.3106 & Milan Đurić & 25 VIII 2018 & FN03 & 1525 \\
\hline 116 & 42.6121 & 22.2978 & Milan Đurić & 19 IX 2018 & FN01 & 1535 \\
\hline 117 & 42.7858 & 22.3573 & Slobodan Ivković & 12 VII 2016 & FN13 & 1539 \\
\hline 118 & 42.7291 & 22.2828 & Bojana Nadaždin & 30 V 2018 & FN03 & 1547 \\
\hline 119 & 42.7291 & 22.2758 & Mihailo Vujić & 03 IX 2019 & FN03 & 1557 \\
\hline 120 & 42.6282 & 22.3237 & Bojana Nadaždin & 22 VII 2019 & FN02 & 1558 \\
\hline 121 & 42.7244 & 22.2917 & Bojana Nadaždin & 02 IX 2019 & FN03 & 1564 \\
\hline 122 & 42.724 & 22.2973 & Mihailo Vujić & 14 VII 2017 & FN03 & 1570 \\
\hline 123 & 42.6323 & 22.3272 & Mihailo Vujić & 11 VII 2016 & FN02 & 1581 \\
\hline 124 & 42.6034 & 22.2909 & Slobodan Ivković & 03 IX 2019 & FN01 & 1587 \\
\hline 125 & 42.6033 & 22.2908 & Slobodan Ivković & 03 IX 2019 & FN01 & 1587 \\
\hline 126 & 42.6130 & 22.2854 & Milan Đurić & 19 IX 2018 & FN01 & 1596 \\
\hline 127 & 42.6027 & 22.2892 & Slobodan Ivković & 03 IX 2019 & FN01 & 1598 \\
\hline 128 & 42.6336 & 22.2774 & Ivan Tot & 24 VII 2019 & FN02 & 1599 \\
\hline 129 & 42.6153 & 22.2817 & Miloš Popović & 11 VII 2016 & FN01 & 1618 \\
\hline 130 & 42.7346 & 22.2795 & Skejo and Ivković (2015) & 18 VII 2014 & FN03 & 1624 \\
\hline 131 & 42.7337 & 22.2772 & Milan Đurić & 07 VII 2016 & FN03 & 1634 \\
\hline 132 & 42.7349 & 22.2776 & Ivan Tot & 06 IX 2016 & FN03 & 1636 \\
\hline 133 & 42.6334 & 22.2757 & Slobodan Ivković & 03 IX 2019 & FN02 & 1637 \\
\hline 134 & 42.6333 & 22.2751 & Slobodan Ivković & 03 IX 2019 & FN02 & 1658 \\
\hline 135 & 42.7937 & 22.3773 & Slobodan Ivković & 13 VII 2012 & FN13 & 1670 \\
\hline 136 & 42.6129 & 22.2820 & Slobodan Ivković & 03 IX 2019 & FN01 & 1670 \\
\hline
\end{tabular}


Appendix 1. (continued)

\begin{tabular}{ccccccc}
\hline Locality No & Northing & Easting & Collector/Publication & Date & $\begin{array}{c}\text { UTM } \\
\text { 10x10 }\end{array}$ & $\begin{array}{c}\text { Altitude } \\
\text { m a.s.l. }\end{array}$ \\
\hline 137 & 42.6120 & 22.2827 & Bojana Nadaždin & 22 VII 2019 & FN01 & 1673 \\
138 & 42.6340 & 22.2694 & Slobodan Ivković & 03 IX 2019 & FN02 & 1675 \\
139 & 42.7917 & 22.3759 & Bojana Nadaždin & 20 VII 2019 & FN13 & 1681 \\
140 & 42.7891 & 22.3705 & Bojana Nadaždin & 05 IX 2019 & FN13 & 1683 \\
141 & 42.6265 & 22.2713 & Milan Đurić & 11 VII 2016 & FN02 & 1690 \\
142 & 42.7929 & 22.3733 & Slobodan Ivković & 13 VII 2012 & FN13 & 1708 \\
143 & 42.7929 & 22.3732 & Skejo and Ivković (2015) & 16 VII 2014 & FN13 & 1708 \\
144 & 42.7928 & 22.3733 & Skejo and Ivković (2015) & 16 VII 2014 & FN13 & 1708 \\
145 & 42.6182 & 22.2780 & Slobodan Ivković & 03 IX 2019 & FN01 & 1709 \\
146 & 42.6316 & 22.2706 & Slobodan Ivković & 03 IX 2019 & FN02 & 1721 \\
147 & 42.6235 & 22.2774 & Slobodan Ivković & 03 IX 2019 & FN01 & 1743 \\
148 & 42.6238 & 22.2711 & Slobodan Ivković & 03 IX 2019 & FN01 & 1787 \\
149 & 42.6256 & 22.2685 & Slobodan Ivković & 03 IX 2019 & FN02 & 1826 \\
150 & 42.6265 & 22.2676 & Slobodan Ivković & 03 IX 2019 & FN02 & 1862 \\
151 & 42.6266 & 22.2674 & Slobodan Ivković & 03 IX 2019 & FN02 & 1863 \\
\hline
\end{tabular}

